\title{
Short Communication: Diversity of Chlorpyrifos-degrading bacteria isolated from shallow aquifer of East Java Coastal Settlements, Indonesia
}

\author{
BASKORO ROCHADDI ${ }^{1}$, MUHAMMAD ZAINURI ${ }^{2}$, AGUS SABDONO ${ }^{3, \bullet}$ \\ ${ }^{1}$ Marine Science Doctoral Program, Department of Marine Science, Faculty of Fisheries and Marine Science, Universitas Diponegoro. Jl. Prof. H. \\ Soedarto, S.H., Tembalang, Semarang 50275, Central Java, Indonesia \\ ${ }^{2}$ Department of Marine Science, Faculty of Fisheries and Marine Science, Universitas Diponegoro. Jl. Prof. H. Soedarto, S.H., Tembalang, Semarang \\ 50275, Central Java, Indonesia. Tel.: +62-24-7474698, Fax.: +62-24-7474698, `email: agus_sabdono@yahoo.com \\ ${ }^{3}$ Department of Oceanography, Faculty of Fisheries and Marine Science, Universitas Diponegoro. J1. Prof. H. Soedarto, S.H., Tembalang, Semarang \\ 50275, Central Java, Indonesia
}

Manuscript received: 15 October 2019. Revision accepted: 22 November 2019.

\begin{abstract}
Rochaddi B, Zainuri M, Sabdono A. 2019. Short Communication: Diversity of Chlorpyrifos-degrading bacteria isolated from shallow aquifer of East Java Coastal Settlements, Indonesia. Biodiversitas 20: 3662-3666. Wastes from inhabited regions, factories and maricultural practices through movement and penetration enter to groundwaters. A study was undertaken to determine the diversity of Chlorpyrifos-degrading bacteria isolated from a shallow aquifer of East Java coastal settlements. Fifteen of 116 bacterial strains isolated from shallow aquifer samples of 12 household wells were selected due to their capability of degrading Chlorpyrifos herbicide. These isolates were different in the ability of Chlorpyrifos degradation. They utilize Chlorpyrifos as the source of carbon and energy for their growth. Their initial degradation at $50 \mathrm{mg} \mathrm{L}^{-1}$ concentration within the first 4 days ranged between 26.81 and $70.12 \%$. The 16S rRNA gene sequence analyses indicated that the majority of the isolates belonged to members of Bacillus genera. These bacterial strains were Bacillus cereus (seven strains) and Bacillus paramycoides (four strains). Besides, three strains were identified as Bacillus subtilis and one strain as Bacillus thuringiensis. Bacillus cereus strain LCA1.1 was selected for further study on kinetic growth and Chlorpyrifos utilization. These bacterial strains have a great potential utility for the bioremediation of shallow aquifer of coastal settlement contaminated with Chlorpyrifos pesticides.
\end{abstract}

Keyword: Bacillus, Chlorpyrifos, coastal settlement, East Java, household wells

\section{INTRODUCTION}

The big cities such as Surabaya, Gresik, Lamongan, and Sidoarjo have high urbanization problems because many industries are established, as a result, various slums arise around them. Clean water is a big problem for residents in coastal urban settlements due to unconnected to the city water supply, then dug wells are an alternative for the water fulfillment of daily life. Though, surface water and groundwater are never pure which may contain various polluted compounds (Shannon et al. 2008). Pollution from coastal settlement, factories, and farming practices through movement and infiltration enter groundwater (Eyles et al. 2013). Hence, exploratory studies on shallow aquifer indigenous bacteria are the most relevant.

Chlorpyrifos pesticides are the most widely used as pest control in Indonesia since the green revolution launched by the government in 1965. Currently, there are several Chlorpyrifos products that are being sold freely in the traditional market. The widespread use of this pesticide has led to wide environmental pollution, such as in the soil, lake and underground water (Isworo et al. 2015). Relyea (2009) reported that some terrestrial and water ecosystems are contaminated by Chlorpyrifos pesticides. The application of Chlorpyrifos pesticides can have an impact on aquatic communities such as plankton, frog and other animals (Bendis and Relyea 2016). Some coral species in the Java Sea waters detected the presence of Chlorpyrifos compounds in coral tissue (Sabdono et al. 2007). As the Chlorpyrifos causes toxicity in the groundwater, the search of indigenous Chlorpyrifos-degrading bacteria as remedy to degrade contaminants is very important.

The Chlorpyrifos pesticide compound has a chemical structure $\quad[\mathrm{O}, \quad \mathrm{O}$-diethyl O-(3,5,6-trichloro-2-pyridyl) phosphorothioate] widely applied as a pesticide in rice farming, plantation and in the house (Wang et al. 2013). The persistence of these pesticide compounds in the soil was reported to be nine weeks (Putnam et al. 2003). This is degraded to 3,5,6-trichloro-2-pyridinol (TCP). One characteristic of these pesticides is the bonding relationship between the P-O-C elements with other organophosphate groups such as diazinon, malathion, and parathion. Among different organophosphate pesticide groups, to date, there have been few reports of the degradation of Chlorpyrifos compounds in shallow groundwater (Lapworth et al. 2018). TCP has antimicrobial properties that can prevent the proliferation of microorganisms in reducing Chlorpyrifos in the soil (Racke et al. 1990).

Microorganisms have a crucial role in degrading organic pollutants. It has been widely reported that some bacteria which are able to degrade chemical contaminants. Their degradation pathways have been investigated in- 
depth, but the evidence about microbial degradation of organophosphates in shallow groundwater in coastal settlements are still very limited. Until now, little research has been reported in shallow groundwater-degrading bacteria Chlorpyrifos. Most of the research has been carried out mainly on soil bacteria, such as Alcaligenes faecalis (Yang et al. 2005), Bacillus fumilis (Li et al. 2008) and Pseudomonas aeruginosa (Lakschmi et al. 2009) that can degrade Chlorpyrifos pesticides.

Several previous studies have been carried out on the identification of bacteria at molecular level that can degrade certain organophosphate pesticide groups. Some of the Chlorpyrifos pesticide degrading genes (mpd and opd gene) were found on several bacteria (Yang et al. 2006) Most of these degradation genes are encoded in their plasmids in the same DNA sequence. In contrast to the results of other studies, Horne et al. (2002) reported that the Chlorpyrifos pesticide degrading gene in Agrobacterium radiobacter bacteria was encoded in its chromosomes, but retained a DNA sequence similar to the opd gene in other bacterial species. This research was carried out to investigate the diversity of Chlorpyrifos degrading bacteria in shallow groundwater in household coastal settlements.

\section{MATERIALS AND METHODS}

\section{Study area}

The water samples were collected randomly in sterile dark bottles from the household wells of East Java, Indonesia coastal settlements, included Lamongan (06 $52^{\prime}$ 48.9" S; $\left.112^{\circ} 14^{\prime} 25.6^{\prime \prime} \mathrm{E}\right)$, Gresik (06 $53^{\circ} 35.9^{\prime \prime} \mathrm{S} ; 112^{\circ}$ 27' 10.3" E), Surabaya (07 13' 26.5" S; $\left.112^{\circ} 46^{\prime} 22.9^{\prime \prime} \mathrm{E}\right)$ and Sidoarjo (07 25' 29.7" S; $112^{\circ} 44^{\prime} 11.1^{\prime \prime}$ E) (Figures1 and 2), put in ice-box stored and were brought directly to the Marine Sciences Laboratory, Diponegoro University, Semarang, Indonesia. Serial dilution of the water sample was carried out before planting in half-strength Zobell's medium, then incubated for 48 hours at room temperature (about $25^{\circ} \mathrm{C}$ ). The colonies were selected and purified based on the color, size, and shape of the colony.

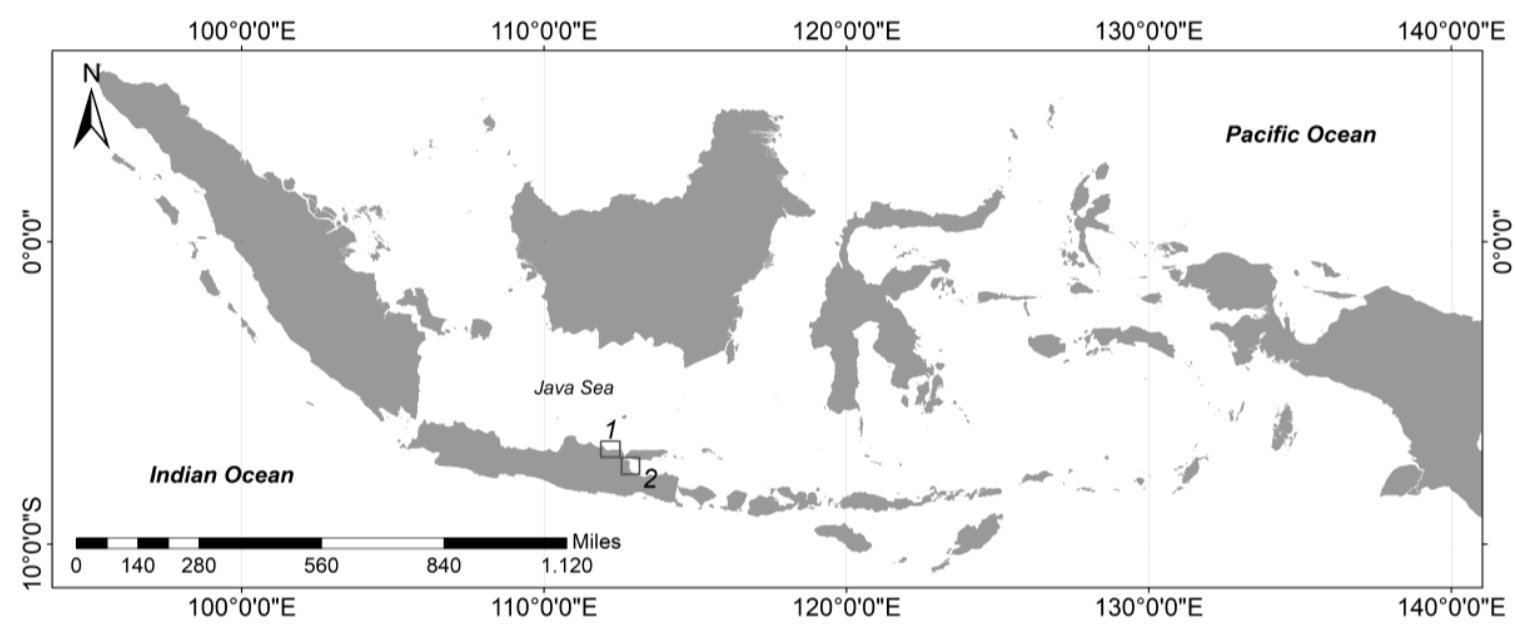

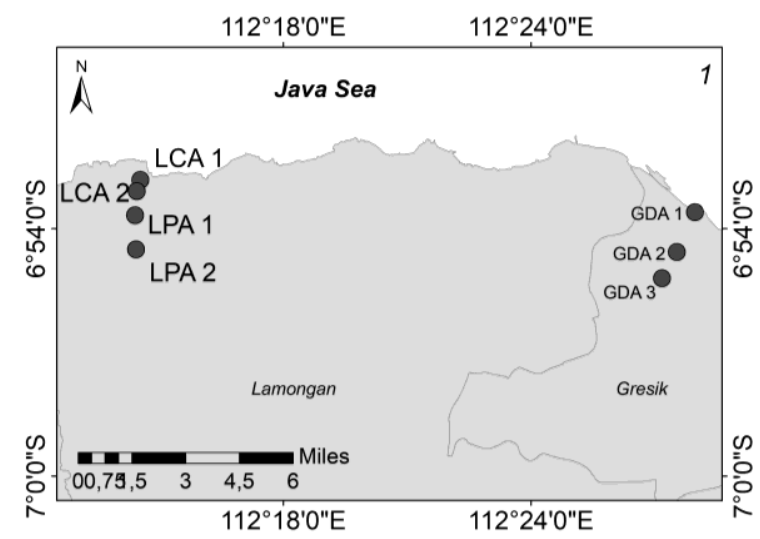

Scale $1: 150.000$

Map Resource : RBI Map 2010

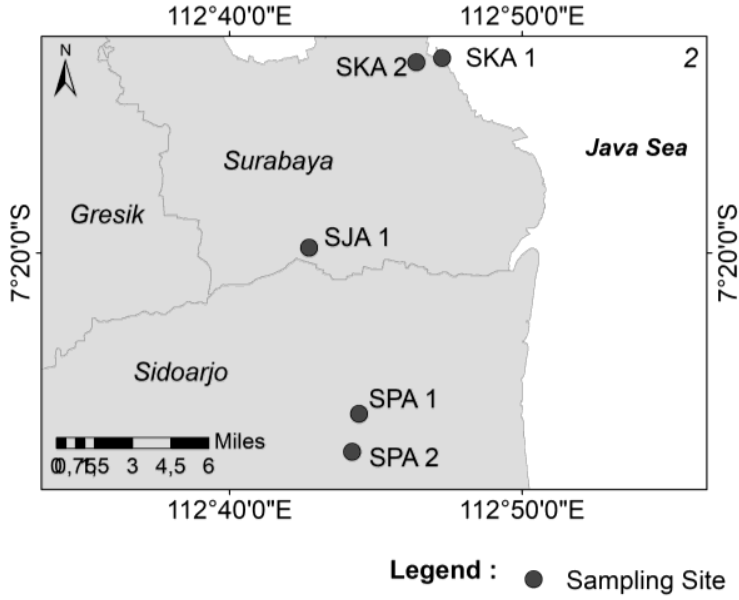

Figure 1. Sampling sites for the collection of water from household wells, East Java, Indonesia 


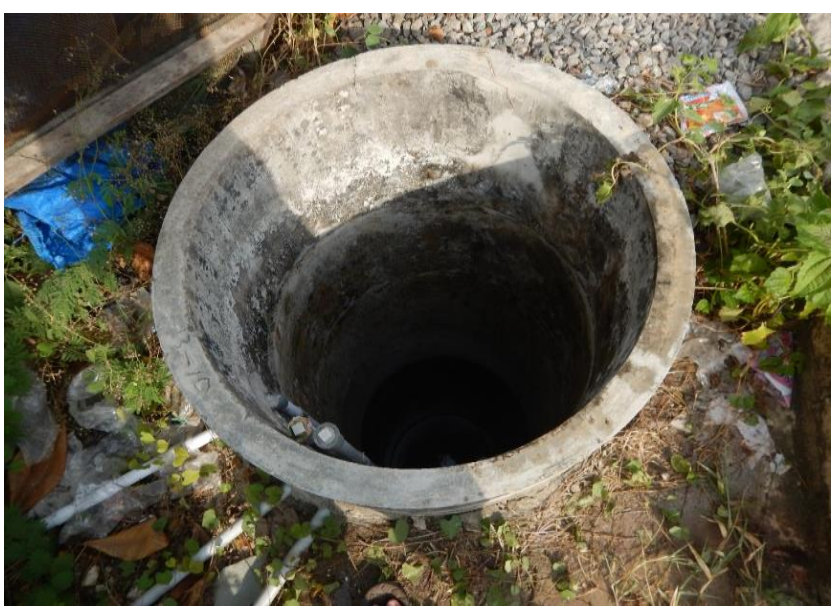

Figure 2. Household well of East Java coastal settlement, Indonesia

\section{Procedures}

Screening of Chlorpyrifos-degrading bacteria

The study of Chlorpyrifos degradation was performed according to the method of Rokade and Mali (2013). Each selected bacterial isolates were inoculated at Nutrient Broth (NB) medium containing $10 \mathrm{~mL}$ of $30 \mathrm{mg}^{\mathrm{L}-1}$ Chlorpyrifos and placed on a rotary shaker at $120 \mathrm{rpm}$ for $96 \mathrm{~h}$ at room temperature. After centrifugated, samples were removed and the supernatant was decanted into Eppendorf. Spectrophotometry at $289 \mathrm{~nm}$ and calibration curves were used to measure Chlorpyrifos concentrations (Figure 3).

\section{Kinetic growth and Chlorpyrifos degradation of LCA1.1 isolate}

Isolate LCA1.1 was inoculated in the Nutrient Broth medium supplemented with $30 \mathrm{mg} \mathrm{L}^{-1}$ Chlorpyrifos in three replications and placed on a rotary shaker at $120 \mathrm{rpm}$ at room temperature. The bacterial growth and remaining Chlorpyrifos were measured by UV vis spectrophotometry after 4, 6, 8 10, 12, 16, 20, 24, 30, 36, 48, 72 and 96 hours. After centrifugated, samples were removed and supernatant was decanted into Eppendorf. Spectrophotometry at 289 $\mathrm{nm}$ and the calibration curve was used to measure Chlorpyrifos concentrations. The LCA1.1 bacterial growth was measured by UV-vis Spectrophotometry at $\lambda=600$ $\mathrm{nm}$.

\section{Phylogenetic study}

For molecular study to DNA was extracted, amplified in PCR purified and sequenced out based on the method of Sabdono et al. (2007). The results of the DNA sequence were then analyzed for their homology by using the BLAST database. The maximum-likelihood analysis was used to construct phylogenetic tree. Multiple alignments/pairwise the DNA sequence was analyzed by Clustal X (Thompson et al. 1997). The PAUP*4.0 software was used to construct phylogenetic tree (Swofford 1998).

\section{Nucleotide sequence accession numbers}

Partial 16S rDNA gene nucleotide sequences of the selected strains were deposited in Genbank database under accession numbers MK694742-MK694756.

\section{RESULTS AND DISCUSSION}

\section{Chlorpyrifos degradation assay}

A total of 116 bacterial strains were isolated from 12 sampling site locations along East Java seashore. Degradation assay was further carried out to screen their ability to utilize or degrade Chlorpyrifos. Bacterial isolates were inoculated in NA medium $+30 \mathrm{mg} \mathrm{L}^{-1}$ Chlorpyrifos, then incubated for $96 \mathrm{hr}$ at room temperature. Culture samples were extracted and analyzed by UV vis spectrophotometry (Rokade and Mali 2013). These bacterial strains were different in the ability to degrade Chlorpyrifos. The assays result showed that 15 (12.93\%) out of 116 strains were able to degrade Chlorpyrifos. These selected isolates were identified molecularly by analyzing the $16 \mathrm{~S}$ rDNA. Several previous studies demonstrated that some bacteria were capable of degrading Chlorpyrifos. Li et al. (2008) found seven Chlorpyrifos-degrading bacteria isolated from pesticide-contaminated soil and water. Meanwhile, Briceno et al. (2012) found four Chlorpyrifosdegrading bacteria isolated from agricultural soil. The degrading ability of 15 strains was observed between 26.81 to $70.12 \%$ (Table 1). Strain LCA1.1 showed the highest degradation among these isolates. This strain was further studied in detail on its growth and substrate utilization.

\section{Growth kinetics and Chlorpyrifos degradation by LCA1.1 strain}

The degrading ability of LCA1.1. the strain was examined in culture media containing Chlorpyrifos. The strain could moderately degrade $30 \mathrm{mg} \mathrm{L}^{-1}$ of Chlorpyrifos during the logarithmic phase of the bacterial growth (12-30 h). The degradation rate gradually slowed down with the decreased bacterial growth rate after $36 \mathrm{~h}$. Approximately $76.6 \%$ of Chlorpyrifos was removed at the $48 \mathrm{~h}$. The results showed that LCA1.1 was capable of utilizing the herbicide Chlorpyrifos as a sole source of carbon and energy (Figure 4). Compared to the previous studies, the LCA1.1 strain could degrade Chlorpyrifos higher than that of Stenotrophomonas sp G1 (Deng et al. 2015). Singh et al. (2004) reported that Enterobacter Strain B-14 hydrolyzed $35 \mathrm{mg} \mathrm{L}^{-1}$ concentration of Chlorpyrifos within $24 \mathrm{~h}$.

Table 1. Chlorpyrifos-degrading bacteria isolated from shallow aquifers of East Java, Indonesia

\begin{tabular}{llc}
\hline No. & Isolate & \% degradation \\
\hline 1. & SPA 1.1 & 55.26 \\
2. & SPA 2.2 & 33.34 \\
3. & LPA 1.1 & 26.81 \\
4. & LPA 2.1 & 28.50 \\
5. & LPA 2.2 & 59,40 \\
6. & LPA 2.3 & 38.24 \\
7. & SKA 1.1 & 34.67 \\
8. & SKA 1.2 & 33.60 \\
9. & SKA 2.1 & 44.17 \\
10. & SKA 2.2 & 38.35 \\
11. & GDA 3.1 & 41.30 \\
12. & GDA 3.2 & 40.77 \\
13. & SJA 1.1 & 45.24 \\
14. & LCA 1.1 & 70.12 \\
15 & GDA 1.1 & 39.53 \\
\hline
\end{tabular}




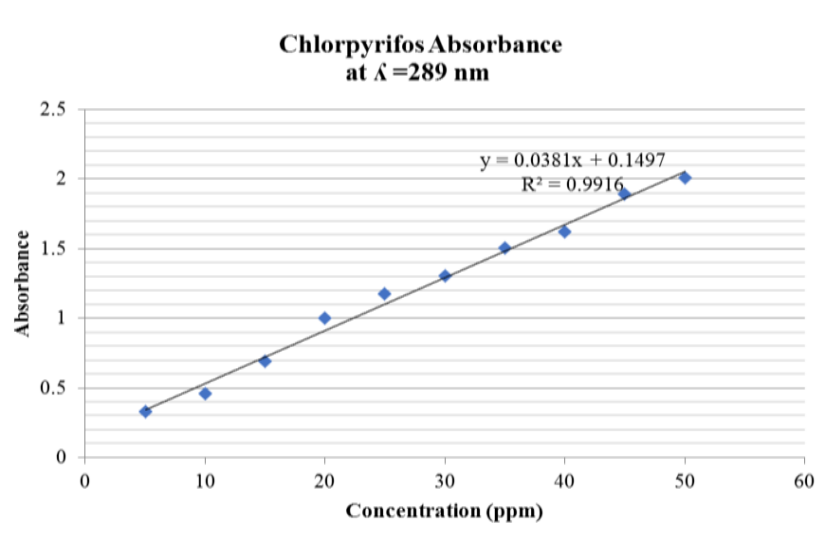

Figure 3. Chlorpyrifos absorbance curve at $K=289 \mathrm{~nm}$

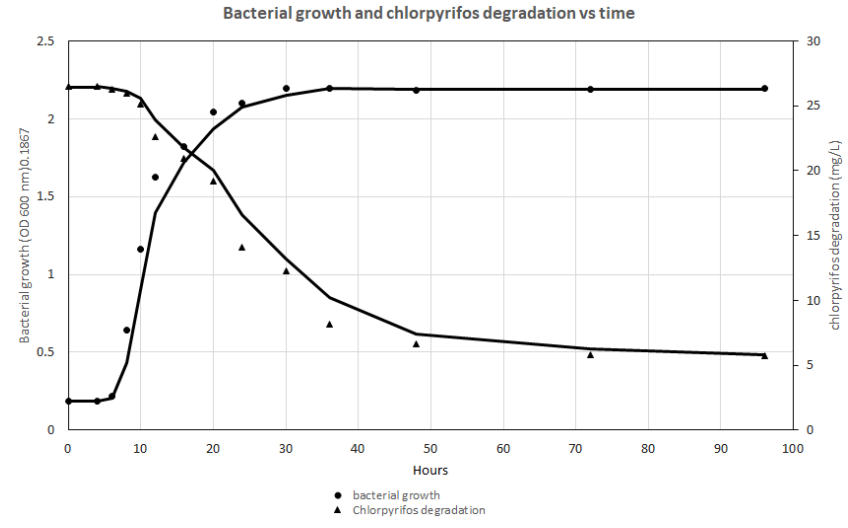

Figure 4. The growth and degradation of Chlorpyrifos by Bacillus cereus strain LCA1.1

Table 2. Homology analyses and Accession No. of 15 Chlorpyrifos-degrading bacteria isolated from shallow aquifer in the coastal settlements of East Java, Indonesia

\begin{tabular}{|c|c|c|c|c|}
\hline Isolate code & Length sequen (bp) & BLAST nucleotide & Homology $(\%)$ & Accession number \\
\hline SPA 1.1 & 1434 & Bacillus cereus strain SPA1.1 & 100 & MK694742 \\
\hline SPA 2.2 & 1426 & Bacillus cereus strain SPA2.2 & 99 & MK694743 \\
\hline LPA 1.1 & 1439 & Bacillus paramycoides strain LPA1.1 & 99 & MK694744 \\
\hline LPA 2.1 & 1425 & Bacillus paramycoides strain LPA2.1 & 99 & MK694745 \\
\hline LPA 2.2 & 1431 & Bacillus thuringiensis strain LPA2.2 & 99 & MK694746 \\
\hline LPA 2.3 & 1445 & Bacillus cereus strain LPA2.3 & 98 & MK694747 \\
\hline SKA 1.1 & 1424 & Bacillus paramycoides strain SKA1.1 & 100 & MK694748 \\
\hline SKA 1.2 & 1443 & Bacillus cereus strain SKA1.2 & 99 & MK694749 \\
\hline SKA 2.1 & 1447 & Bacillus cereus strain SKA2.1 & 99 & MK694750 \\
\hline SKA 2.2 & 1424 & Bacillus paramycoides strain SKA2.2 & 99 & MK694751 \\
\hline GDA 3.1 & 1444 & Bacillus subtilis strain GDA3.1 & 99 & MK694752 \\
\hline GDA 3.2 & 1437 & Bacillus subtilis strain GDA3.2 & 99 & MK694753 \\
\hline SJA 1.1 & 1439 & Bacillus subtilis strain SJA1.1 & 99 & MK694754 \\
\hline LCA 1.1 & 1437 & Bacillus cereus strain LCA1.1 & 99 & MK694755 \\
\hline GDA 1.1 & 1239 & Bacillus cereus strain GDA1.1 & 100 & MK694756 \\
\hline
\end{tabular}

Rokade and Mali (2013) showed Pseudomonas desmolyticum NCIM 2112 could degrade $63.52 \%$ after $96 \mathrm{~h}$ of incubation.

\section{Phylogenetic study}

In this research, 15 Chlorpyrifos-degrading strains were obtained from several shallow aquifers in the coastal settlement of East Java. Their 16S rDNA gene was sequenced to investigate the phylogenetic and evolutionary correlations among the bacterial strains. The DNA sequences of 15 bacterial strains were successfully amplified using PCR, and identified by using BLAST nucleotides based on GenBank databases. The sequence DNA analysis showed that nucleotide identities varying from $98 \%$ to $100 \%$ based on the consensus sequences of 4 species, namely, Bacillus cereus, Bacillus subtilis, Bacillus paramycoides and Bacillus thuringiensis (Table 2). Phylogenetic analysis clustered the isolates into two groups (Figure 5).

Bacillus genera are recognized for the making of wide range of medicinal, agricultural, pharmaceutical and industrial products, example.g., Bacillus tequilensis as alginate lyase producer (Zilda et al. 2019), Bacillus subtilis MA9 produce thermostable $\alpha$-amylase enzyme (Devi et al. 2010), Bacillus cereus KKT 1, B. cereus KKT 14, B. cereus KKT 19. Bacillus thuringiensis KKT 6, produce chitin-degrading enzyme (Puspita et al. 2017) and $B$. cereus, B. subtilis B. thuringiensis, and B. pumilus as antibiotic-producing agent (Amin et al. 2015; Magda and Hamed 2016). Some bacteria were also reported to degrade Chlorpyrifos pesticide,i.e. Bacillus cereus (Liu et al. 2012), Xanthomonas sp. 4R3M1, Rhizobium sp. 4H1-M1 and Pseudomonas sp. 4H1-M3 (Rayu et al. 2017), and Achromobacter xylosoxidans JCp4 and Ochrobactrum sp FCp1 (Akbar and Sultan 2016). However, all of those bacteria were isolated from soil. On the basis of literature published so far, this is the first research that intended to investigate the indigenous aquifer bacteria capable of degrading Chlorpyrifos pesticide. This was an important finding, since there was concern that the Chlorpyrifos degrading bacterial strains have the potential to develop into promising candidates for bioremediation of removing pesticide pollutants from shallow groundwater. 


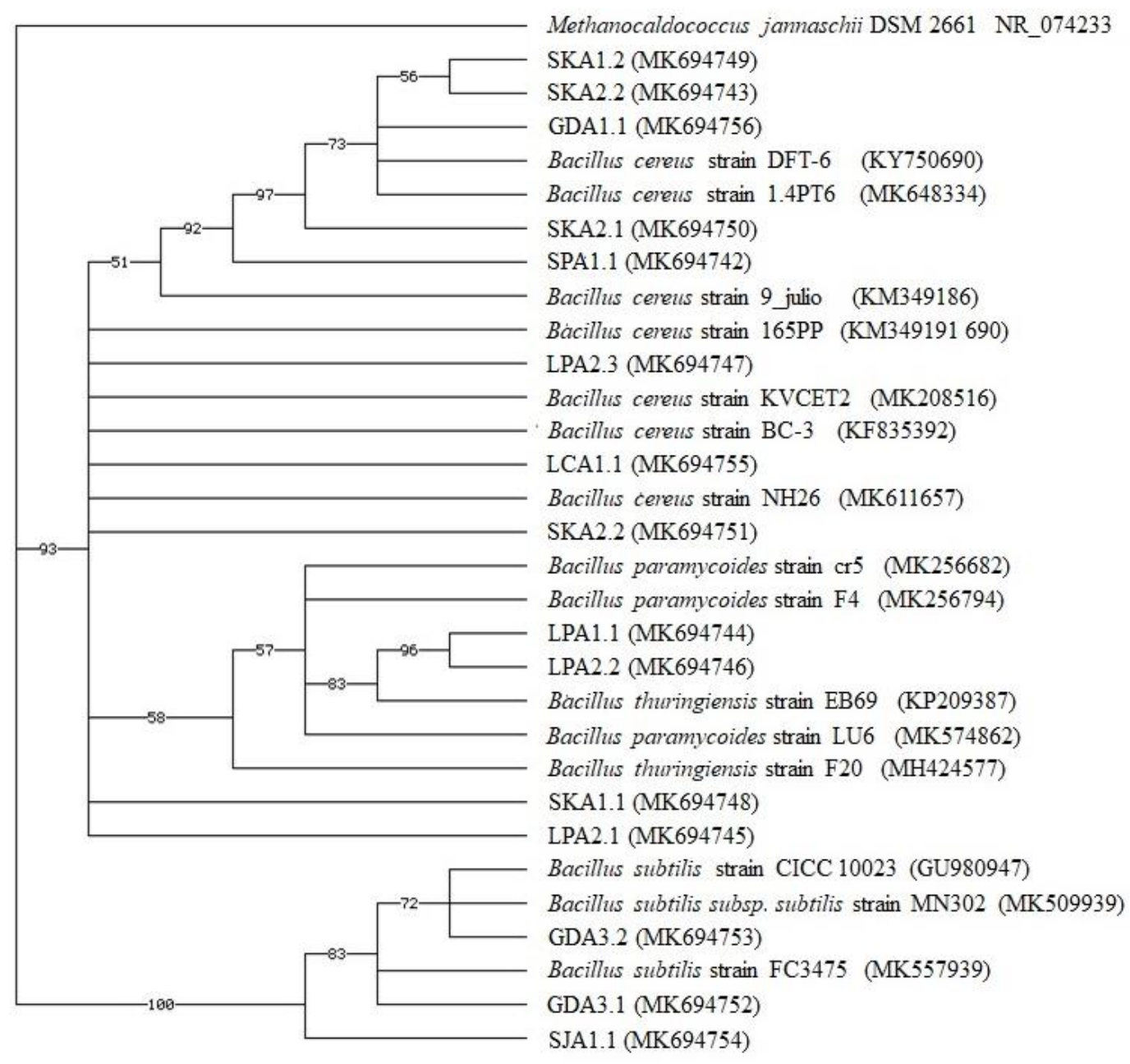

Figure 5. Phylogenetic tree based on comparative 16S rRNA gene sequence analysis of Bacillus species showing the phylogenetic affiliation of East Java strains. Methanocaldococcus jannaschii DSM 2661 NR_074233was used as outgroup.

\section{ACKNOWLEDGEMENTS}

The authors would like to thank Prof. Magaly Koch for her expert advice and encouragement throughout this difficult project, as well as Abi for his brilliance in the technical laboratory.

\section{REFERENCES}

Akbar S, Sultan S. 2016. Soil bacteria showing a potential of Chlorpyrifos degradation and plant growth enhancement. Braz J Microbiolol 47: 563-570.

Amin M, Rakhisi Z, Ahmady AZ. 2015. Isolation and identification of Bacillus species from soil and evaluation of their antibacterial properties. Avicenna J Clin Microbiol Infec 2 (1): 10-13

Bendis RJ, Relyea RA, 2016. Wetland defense: naturally occurring pesticide resistance in zooplankton populations protects the stability of aquatic communities. Oecologia 181 (2): 487-498

Briceno G, Fuentes MS, Palma G, Jorquera MA, Amoroso MJ, Diez MC. 2012. Chlorpyrifos biodegradation and 3, 5, 6-trichloro-2-pyridinol production by actinobacteria isolated from soil. Int Biodeterior Biodegrad 73: 1-7.
Devi SL, Khaund P, Joshi SR. 2010. Thermostable $\alpha$-amylase from natural variants of Bacillus spp. prevalent in eastern Himalayan range, Afr J Microbiol Res 4: 2534-2542.

Eyles N, Meriano M, Chow-Fraser P. 2013. Impacts of European settlement (1840-present) in a Great Lake watershed and lagoon: Frenchman's Bay, Lake Ontario, Canada. Environ Earth Sci (2013) 68 (8): 2211-2228 DOI: 10.1007/s12665-012-1904-8

Deng SY, Chen Y, Wang DS, Shi TZ, Wu XW, Ma X, Li XQ, Hua RM, Tang XY, Li QX.2015. Rapid biodegradation of organophosphorus pesticides by Stenotrophomonas sp G1. J Hazard Mater 297: 17-24

Horne I, Sutherland TD, Harcourt RL, Russell, RJ, Oakeshott JG. 2002. Identification of an OPD (Organophosphate Degradation) gene in an Agrobacterium isolate. Appl Environ Microbiol 68 (1): 3371-3376

Isworo S, Purwanto I, Sabdono A. 2015. Impact of Pesticide Use on Organophosphorus and Organochlorine Concentration in Water and Sediment of Rawa Pening Lake, Indonesia. Res J Environ Sci 9 (5): 233-240.

Lakshmi C, Kumar M, Khanna S. 2009. Biodegradation of Chlorpyrifos in soil enriched cultures. Curr Microbiol 58 35-38.

Lapworth DJ, Das P, Shaw A, Mukherjee A, Civil W, Petersen JO, Gooddy DC, Wakefield O, Finlayson A, Krishan G, Sengupta P, MacDonald AM. 2018. Deep urban groundwater vulnerability in India revealed through the use of emerging organic contaminants and residence time Tracer. Environ Pollut 240: 938-949

Li X, Jiang J, Gu L, Ali SW, He J, Li S. 2008. Diversity of Chlorpyrifosdegrading bacteria isolated from Chlorpyrifos-contaminated samples. Int Biodeterior Biodegrad 62: 331-335 
Liu Z, Chen X, Shi Y, Su Z. 2012. Bacterial degradation of Chlorpyrifos by Bacillus cereus. Adv Mater Res 356 (360): 676-680

Magda AE, Hamed HAMM. 2016 Potential of Bacillus isolates as biocontrol agents against some fungal phytopathogens. Biocatal Agric Biotechnol 5: 173-178.

Puspita ID, Wardani A, Puspitasari ROA, Nugraheni PS, Putra MMP, Pudjiraharti S, Ustadi. 2017. Occurrence of chitinolytic bacteria in shrimp rusip and measurement of their chitin-degrading enzyme activities. Biodiversitas 18: 1275-1281. [Indonesian]

Putnam RA, Nelson JO, Clark JM. 2003. The persistence and degradation of chlorothalonil and Chlorpyrifos in a cranberry bog. J Agric Food Chemi 51 (1): 170-176.

Racke KD, Laskowski DA, Schultz MR. 1990. Resistance of paraquat dichlor to enhanced biodegradation in soil. J Agric Food Chem 38: 1430-1436.

Rayu S, Nielsen UN, Nazaries L, Singh BK. 2017. Isolation and Molecular Characterization of Novel Chlorpyrifos and 3,5,6trichloro2-pyridinol-degrading Bacteria from Sugarcane Farm Soils. Front Microbiol 8: 518. DOI: 10.3389/fmicb.2017.00518.

Relyea RA. 2009. A cocktail of contaminants: how mixtures of pesticides at low concentrations affect aquatic communities. Oecologia 159 (2): 363-376.

Rokade KB, Mali GV. 2013. Biodegradation of Chlorpyrifos by Pseudomonas desmolyticum NCIM 2112. Intl J Pharm Bio Sci 4 (2): 609-616.

Sabdono A, Kang S, Hur HG, Grossart HP, Simon M, Radjasa OK. 2007. Organophosphate pesticide concentration in coral tissues of indonesian coastal waters. Pak J Biol Sci 10 (11): 1926-1929
Swofford DL. 1998. PAUP*. Phylogenetic Analysis Using Parsimony (*and Other Methods). Version 4. Sinauer Associates, Sunderland, Massachusetts. Copyright @) Smithsonian Institution, 1998

Singh BK, Walker A, Morgan JAW, Wright DJ. (2004). Biodegradation of Paraquat dichlor by Enterobacter Strain B-14 and its use in bioremediation of contaminated soils. Appl Environ Microbiol 70: 4855-4863

Shannon MA, Bohn PW, Elimelech M, Georgiadis JG, Marinas, BJ, Mayes AM. 2008. Science and technology for water purification in the coming decades. Nature 452 (20): 301-310

Thompson JD, Gibson TJ, Plewniak F, Jeanmougi F, Higgins DG. 1997. The Clustal X-Window interface: Flexible strategies for multiple alignments through sequence alignment aided by quality analysis tools. Nucl Acids Res 25: 4876-4882.

Wang S, Zhang C, Li K, Qu J, Shi Y, Yan Y. 2013. Chlorpyrifos-induced stress response in the Chlorpyrifos-degrader Klebsiella sp. CPK. Int Biodeterior Biodegrad 82: 17-23.

Yang L, Zhao Y, Zhang B, Yang C, Zhang X. 2005. Isolation and characterization of Chlorpyrifos and 3,5,6-trichloro-2-pyridinol degrading bacterium. FEMS Microbiol Lett 251 (1): 67-73. DOI: 10.1016/j.femsle.2005.07.031

Yang C, Liu N, Guo X, Qiao C. 2006. Cloning of mpd gene from a Chlorpyrifos-degrading bacterium and use of this strain in bioremediation of contaminated soil. FEMS Microbiol Lett 265: 118125. DOI: $10.1111 / j .1574-6968.2006 .00478 . x$.

Zilda DS, Yulianti Y, Sholihah RF, Subaryono S, Fawzya YN, Irianto HE. 2019. A novel Bacillus sp. isolated from rotten seaweed: identification and characterization alginate lyase its produced. Biodiversitas 20: 1166-1172. 